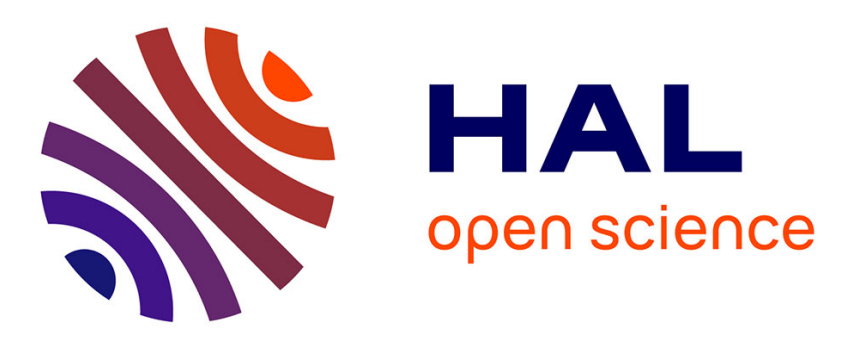

\title{
Characterization of Bean Seeds, Germination, and Phenolic Compounds of Seedlings by UV-C Radiation
}

Claudia Hernandez-Aguilar, Arturo Dominguez-Pacheco, Mariana Palma Tenango, Carmen Valderrama-Bravo, Marcos Soto Hernández, Alfredo

Cruz-Orea, Jose Ordonez-Miranda

\section{To cite this version:}

Claudia Hernandez-Aguilar, Arturo Dominguez-Pacheco, Mariana Palma Tenango, Carmen Valderrama-Bravo, Marcos Soto Hernández, et al.. Characterization of Bean Seeds, Germination, and Phenolic Compounds of Seedlings by UV-C Radiation. Journal of Plant Growth Regulation, 2021, 40, pp.642-655. 10.1007/s00344-020-10125-0 . hal-03017601

\section{HAL Id: hal-03017601 \\ https://hal.science/hal-03017601}

Submitted on 28 Nov 2020

HAL is a multi-disciplinary open access archive for the deposit and dissemination of scientific research documents, whether they are published or not. The documents may come from teaching and research institutions in France or abroad, or from public or private research centers.
L'archive ouverte pluridisciplinaire HAL, est destinée au dépôt et à la diffusion de documents scientifiques de niveau recherche, publiés ou non, émanant des établissements d'enseignement et de recherche français ou étrangers, des laboratoires publics ou privés. 


\section{CHARACTERIZATION OF BEAN SEEDS, GERMINATION AND FENOLIC COMPOUNDS OF SEEDLINGS BY UV-C RADIATION}

Claudia Hernandez-Aguilar ${ }^{1}$ (orcid- 0000-0002-0952-1510), Arturo Dominguez-Pacheco ${ }^{1}$ (orcid0000-0003-3561-7257), Mariana Palma Tenango ${ }^{1}$ (orcid-0000-0002-4361-4702), Carmen Valderrama-Bravo²(0000-0002-3880-5782), Marcos Soto Hernández ${ }^{3}$ (orcid-0000-0001-85777991), Alfredo Cruz-Orea ${ }^{4}$ (orcid- 0000-0002-4329-5449), José Ordonez-Miranda ${ }^{5}$ (orcid- 00000001-9463-4597)

${ }^{1}$ Programa en Ingeniería de Sistemas-SBAAM, SEPI-ESIME, Instituto Politécnico NacionalESIME Zacatenco, Col. Lindavista. 07738, Ciudad de México, México.

${ }^{2}$ FES-Cuautitlán, Universidad Nacional Autónoma de México (UNAM), Campus 4, km 2.5 Carretera Cuautitlán-Teoloyucan, San Sebastian Xhala C.P. 54714, Edo de México, México.

${ }^{3}$ Posgrado de Botánica. Colegio de Postgraduados, Campus Montecillo, Texcoco, Edo. De México.

${ }^{4}$ Departamento de Física, CINVESTAV-IPN, A. P. 14-740. 07360, Ciudad de México, México.

${ }^{5}$ Institut Pprime, CNRS, Université de Poitiers, ISAE-ENSMA, F-86962 Futuroscope, Chasseneuil, France.

Corresponding author e-mail: clauhaj@yahoo.com

Telephone: 00+52+55+5729600, Ext.: 54807

Mobile: $00+52+55+91086594$

0 1 2 3 4 5 6 7 8 9 0 1 2 3 
22 5 6 7 8 9 0 1

\section{CHARACTERIZATION OF BEAN SEEDS, GERMINATION AND FENOLIC COMPOUNDS OF SEEDLINGS BY UV-C RADIATION}

(1)

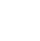

(1)

\section{ABSTRACT}

We quantitatively evaluate the effects of UV-C radiation on bean seeds Oti (Phaseolus vulgaris), their germination and phenolic compounds of seedlings, by means of photoacoustic spectroscopy and scanning electron microscopy. It is shown that: $i$ ) The photoacoustic signal produced by the bean seeds exposed to UV$\mathrm{C}$ radiation during 15 minutes, reduces from 0.24 to $0.10 \mathrm{mV}$ for the wavelengths of 295 and $340 \mathrm{~nm}$, as a result of their degradation. This significant reduction of 58.3\% decreases, but keeps over $50 \%$ for other spectral UV wavelengths within the interval (270-400 nm). ii) As the UV-C radiation time increases from 2 to $15 \mathrm{~min}$, the morphological changes at the surface of the bean seeds exhibits micro-holes and detachment of the cotyledon sclereids. iii) There are no significant statistical differences in the variables of germination, dry weight and seedling length, for exposure times up to 15 minutes. $i v$ ). The phenolic acids and flavonoids of the bean seedlings of seeds treated by UV-C for different exposure times $(0,2,5,10$ and $15 \mathrm{~min})$ display significant statistical differences $(P \leq 0.05)$ in both roots and foliage. For both the roots and foliage, the highest concentration of phenolic acids is observed at 10 and 15 minutes, while for root flavonoids, it appears at 5 and 15 minutes.

Key words: bean seeds, secondary metabolites, UV-C radiation, photoacoustic spectroscopy. 3

\section{(1)}




\section{INTRODUCTION}

One of the challenges of the humanity is to improve food production in quantity and quality for a current population over 7 billion and projected for 2050 of 9 billion (FAO 2009a;2009b; Baulcombe et al. 2009; Godfray et al. 2010; Araujo et al. 2016), reducing the environmental impact (Edmondson et al. 2014; Hernández et al. 2016). Therefore, it is necessary to reduce the use of chemical products in the production process of food (Altieri 2014). For this purpose, in this century has been intensified research into alternative physical methods that are called "emerging technologies" in response to the needs of the modern world (Rifna et al. 2019). Which could help stop the destructive processes of the soil, the environment and protect the production of food and consequently the health and quality of life of the population (Vasilevski 2003; Hernández et al. 2016).

In this way, there are various physical methods, used in different phenological stages, by them could interest the pre-sowing stage (Hernández et al. 2006; 2007;2009; Aladjadjiyan 2008). The pre-sowing methods allow a conditioning of the seed; producing beneficial effects in early stages of growth (Thomas and Pothur 2016; Aladjadjiyan 2012), as in germination, which conditions the vigor of the plants and could be the basis for intensification of crop production (Mariz-Ponte et al. 2018). Physical methods for seed invigoration have advantages over conventional treatments based on chemical substances, e.g. reduce the use of fertilizers, fungicides and pesticides, etc., thus could decreasing pollution (Rifna et al. 2019; Aladjadjiyan 2012). Within these emerging physical methods, are those based on technology laser, led, magnetic and electric fields, nonthermal plasma, ultrasound, ionizing radiation (gamma rays and x-rays), microwave, ozone, magnetically treated water, electrolyzed oxidizing water, and Ultraviolet (UV) radiation, among others (Vasilevsky 2003; Marinković et al. 2008; Hernandez et al. 2010;2016; Aladjadjiyan 2012; Occhipinti 2014; Maffei 2014; Araujo et al. 2016; Thomas and Pothur 2016; Rifna et al. 2019).

Ultraviolet radiation to low levels for treatment of seeds is an ecologically safe method, then, an environmentally-friendly alternative to improve plant productivity, yield quality and as well as to induce tolerance of plants to various biotic and abiotic stresses (Forges et al. 2018; Thomas and Puthur, 2016; Ehsanpour and Razavizadeh 2005). UV light is an electromagnetic radiation of wavelengths shorter than the visible region, but longer than X-rays (Shetta and Areaf 2009). UV radiation has been classified as: UV-A (320$400 \mathrm{~nm}$ ), called black light, UV-B (280-320 nm), called medium wave and UV-C (200-280 nm), called short wave or germicidal (Katerova and Todorova 2009; Shetta and Areaf 2009). The damaging effect of UV radiation increases towards shorter wavelengths: UV-A is less effective than UV-B, while UV-C photons are highly energetic, and quickly create high levels of damage (Katerova and Todorova 2009; Barta et al. 2004; Stapleton 1992).

The UV light continuous or pulsed has been studied to have a broad application in the food and agriculture industry (Elmnasser et al. 2007; Gómez-López et al. 2007; Alexieva et al. 2001; Mukhopadhyay and Ramaswamy 2012). In particular, in the agriculture, the UV-C radiation non-ionizing continuous have shown 
to stimulate positive impact on seed health, germination (G), and seedling vigor (SV), also has been applied in different fruit, vegetable and legume crops, among others (Sukthavornthum et al. 2018; Dawar 2013). In legumes, most applications have focused on the health-related effects of seed, seedlings, seedling roots and / or crops (fungal control and sterilizing effects) (Dawar 2013; Siddiqui et al. 2011), as well as the effects at the level of seedlings and plants radiated with UV-C (Da Silva 2019; Kara 2013) and to a lesser degree, physiological effects (G and SV) and / or of secondary metabolites caused by UV-C light when is used as presowing treatment to the seed and as well the possible degradation produced in it. Among the legumes, most consumed in various countries of the world, e.g. Africa, India, Latin America and Mexico is the bean (ChávezMendoza and Sánchez 2017).

In this way, the present investigation experimental aims are: a) to investigate the degradation of bean seed treated with UV-C light using Photoacoustic spectroscopy (PAS), as well as to evaluate their morphological changes by means of scanning electron microscopy, b) evaluate the physiological quality of the seed (through the germination, seedling length and dry weight) and the phenolic compounds (phenolic acids and flavonoids) of the seedlings grown from seed treated with UV-C radiation prior to sowing.

Globally 800 million people are malnourished (Broughton et al. 2003), being one problems in Mexico and other countries in the world. Beans are considered important because they are a source of protein, fiber, iron, complex carbohydrates, minerals and vitamins (Grela et al. 2017). In addition, characteristics of Nutraceuticals compounds have been identified as polyphenols, flavonoids and anthocyanins (Lin et al. 2008). In such a way that it is a healthy option for the consumption of the human population. For this reason, it is one of the crops that requires improving its production.

\section{MATERIALS AND METHODS}

\section{Biological material}

In the present research project, bean seeds "Oti" (Phaseolus vulgaris L.) of the cycle productive vegetation period 2017 were used. These have been provided by the Mexican Genetic Quality control assurance instituteSeed Program of the "Instituto de Recursos Genéticos y Productividad del Colegio de Postgraduados"(IREGEP). The seed lot was standardized and 100-seed weight averages were $31.84 \mathrm{~g}$ and length, width and thickness $\left(l_{s}\right)$, were about $11.508 \pm 0.56,7.6 \pm 0.39$ and $5.24 \pm 0.5 \mathrm{~mm}$, respectively. The measurements were realized by digital micrometer (Mitutoyo).

\section{Treatment of UV-C radiation}

After homogenizing the bean seed, it was treated pre-sowing, with UV-C radiator system (UV-C/RSHomemade). The system consisted of an arrangement of 4 lamps (UV-C, $254 \mathrm{~nm}$ ) accommodated on the top and bottom of a cylindrical stainless steel base (Figure 1). The lamps when turned on emits light towards a rotating wire-mesh container. Bean seeds were positioned in this container. Several radiation times were applied 
to the seeds: $0,2,5,10$ and $15 \mathrm{~min}$, programmed through a timer. The light intensity measured by the UV$\mathrm{C} / 254$ measuring equipment was of $700 \mu \mathrm{w} / \mathrm{cm}^{2}$.

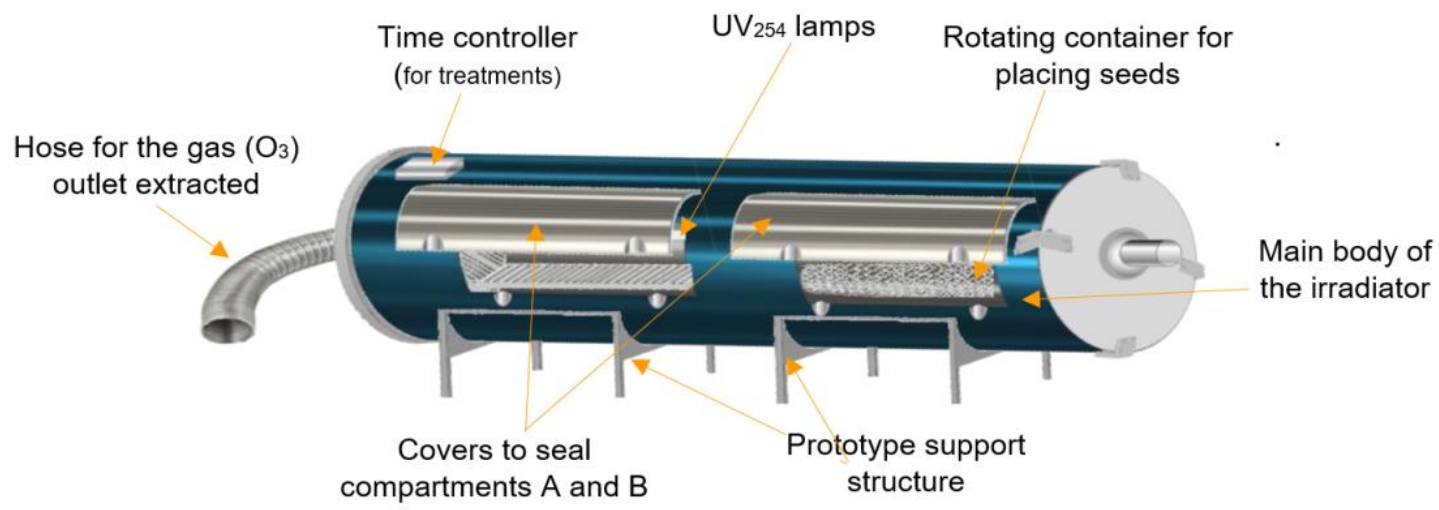

Figure 1 UV-C radiator system

\section{PAS EXPERIMENTAL SETUP}

The experimental setup of PAS consists of a Xenon lamp used as the light excitation source, a monochromator applied to obtain a monochromatic light beam, and a mechanical chopper employed to modulate the light beam at the fixed frequency $f=17 \mathrm{~Hz}$, as shown in Fig. 2. The modulated beam was focused onto an optical fiber to guide it to the Photoacoustic (PA) cell, whose signal was then detected by an electret microphone (Photoacoustic sensor) connected to the cell through a fine channel (1 $\mathrm{mm}$ diameter). The PA signal was amplified by means of a Lock-in amplifier (EG\&G, Mod. 5210) before being recorded on a personal computer, as a function of beam wavelength. Experiments were performed for wavelengths between 275 to $700 \mathrm{~nm}$ and by placing the samples into the PA cell with a diameter of $6 \mathrm{~mm}$. The samples of bean seeds of each treatment UV-C were prepared on a circular form and diameter of $5 \mathrm{~mm}$, such that they do not obstruct the microphone sensor and can be measurements when located inside the Photoacoustic cell.

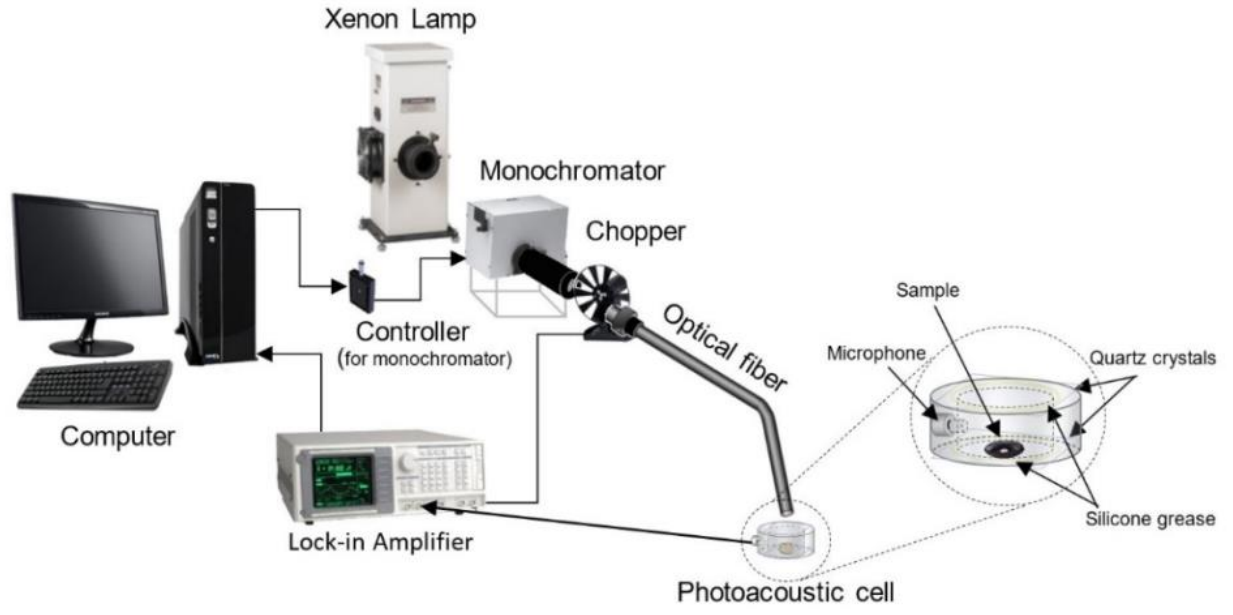

Figure 2 Scheme of the PAS experimental setup used in our experiments. 
Calculation of absorption coefficient and optical penetration length.

2 The determination of the absorption coefficient $(\beta)$ and optical penetration length $\left(l_{\beta}\right)$ of the bean seed were

3 determined from the equation of Poulet et al. (1980), as has been indicated by Hernández et al. (2011a; 2011b)

4 for the characterization of agricultural plant seed. It is possible to observe in equation (1), $\beta$ is a function of the

$5 \quad$ PA signal of amplitude $(q)$ obtained by the PAS

$$
\beta=\frac{q}{\mu_{s}} \frac{q+\sqrt{2-q^{2}}}{1-q^{2}},
$$

7 Which it was used after verification of the condition thermal thickness of the seed: $l_{s} / \mu_{s} \gg>1$, where $\mu_{s}=\sqrt{\alpha / \pi f}$

8 is the thermal diffusion length for the frequency of $17 \mathrm{~Hz}$; finally, $\alpha$ and $l_{s}$ the sample thermal diffusivity and 9 thickness, respectively.

10 The $q=$ PA signal of normalized amplitude, $\alpha=$ thermal diffusivity. In this case, the value corresponding to 11 simple starch was used $=4.44 \times 10^{-3} \mathrm{~cm}^{2} / \mathrm{s}$ (Sanchez et al. 2014). Finally, the optical penetration length $l_{\beta}$ was 12 calculated from the inverse of $\beta$, being $l_{\beta}=1 / \beta$.

\section{Scanning electron microscopy}

14 The morphological changes of the beans seeds, control and treated with the exposition times of UV-C radiation 15 (2, 5, 10 and $15 \mathrm{~min}$ ) were analyzed with a scanning electron microscope (JEOL JSM-6010LA, Tokyo, Japan) under high vacuum. The whole bean seeds were cut in half, placed in an aluminum sample holder, and fixing them with a carbon tape. The samples were covered with gold nanoparticles. The micrographs were obtained from the surface of the whole bean seeds at $5000 \mathrm{x}$. In the bean cut in half, the test and starches were analyzed at $1000 \mathrm{x}$. The conditions of analysis in the equipment were $15 \mathrm{kV}$ of voltage of acceleration of electrons.

\section{Germination test}

22 Germination test was established under a randomized complete block design, with five repetitions and 20 seeds

23 as an experimental unit. Seeds after irradiation were seeded on absorbent paper (double $24 \times 23.2 \mathrm{~cm}$ ) moistened;

24 with $40 \mathrm{ml}$ of distilled water.

25 The germination stage was considered finished 12 days after the experiment was established. The temperature and humidity conditions corresponded to an average temperature of $24.9{ }^{\circ} \mathrm{C}$ and $26 \%$ humidity. At the end of

27 the germination, fresh weight of seedlings was obtained, and subsequently their dry weight. Roots and foliage 28 were separated to obtain biomass dry weight after drying in an oven (Felisa@ Model 293) at $45^{\circ} \mathrm{C}$ for $48 \mathrm{~h}$. After drying the bean seedling organs were milled and sieved (U.S.A. Standard testing sieve $\mathrm{NO}^{\circ} 50300$ micrometer 0.117 inches). Then were perform the analysis by HPLC. 


\section{Analysis by HPLC}

Extracts were obtained with $50 \mathrm{mg}$ of dry and pulverized material in $1 \mathrm{~mL}$ of methanol of HPLC grade (SigmaAldrich number 36860) at $80 \%$, incubated for $20 \mathrm{~min}$ in an ultrasound bath (BRANSON at Smithkline company 50/60 Hz, model B-220, USA) (Meneses Reyes et al. 2008). The crude extracts were centrifuged at $731 \mathrm{~g}$ (Centrifuge 5804 eppendorf, model 5804) for $10 \mathrm{~min}$ (Irakli and Ekateriniadou, 2018). Supernatants were filtered with $25 \mathrm{~mm}$ diameter acrodiscs with nylon membrane and $0.45 \mathrm{~mm}$ pore size (Titan). These extracts were injected immediately for the analysis by HPLC of phenolic acids and flavonoids. For the analysis of free flavonoids additionally a hydrolysis was made exposing the extracts at $70{ }^{\circ} \mathrm{C}$ for one hour. Each extract was realized in duplicate.

\section{Phenolic acids}

The samples were analyzed in a Hewlett Packard® chromatograph mod. 1100 provided with diode array detector and an Agilent Technologies automatic injector model 1200. The column was a Nautilus 125 x $4.0 \mathrm{~mm}$ d. i., $5 \mu \mathrm{m}$. The mobile phase was distilled water adjusted to $\mathrm{pH} 2.5$ with trifuoracetic acid and acetonitrile. The analysis was by gradient: T1 $0.10 \mathrm{~min}(85 \% \mathrm{~A})(15 \% \mathrm{~B})$; T2 $20 \mathrm{~min}(65 \% \mathrm{~A})(35 \% \mathrm{~B})$ and $\mathrm{T} 323 \mathrm{~min}(65 \%$ A), $(35 \% \mathrm{~B}), \lambda=280 \mathrm{~nm}$, column temperature $30^{\circ} \mathrm{C}$ and flow of $1 \mathrm{~mL} \mathrm{~min}^{-1}$ (Bilia et al. 2001). Calibration curves were performed for the galic acid, chlorogenic acid, syringic acid, vanillic acid, p-hydroxybenzoic acid, caffeic acid, ferulic acid and p-coumaric acid standards (Sigma-Aldrich).

\section{Flavonoids}

\section{Flavonoid glycosides}

A Nucleosil 100-5 C-18 Nautilus 125 x 4.0 mm d. i., $5 \mu \mathrm{m}$ column was used. The mobile phase was distilled water adjusted to pH 3 with H3PO4 (A) and acetonitrile (B). The analysis was by gradient: T1 $0.10 \mathrm{~min}(88 \%$ A) (12\% B); T2 $10 \min (82 \%$ A) (18\% B), T3 $15 \min (82 \%$ A), (18\% B), T4 $30 \min (55 \%$ A), (45\% B) and T5 $32 \mathrm{~min}(0 \% \mathrm{~A}),(10 \% \mathrm{~B}), \lambda=254,316,365 \mathrm{~nm}$, column temperature $30{ }^{\circ} \mathrm{C}$ and flow of $1.3 \mathrm{~mL} \mathrm{~min}{ }^{-1} ; \lambda=350$ $\mathrm{nm}$ and the column temperature was $30^{\circ} \mathrm{C}$ (Bilia et al. 2001). Calibration curve was performed for apigenin-70-glucoside, phlorizin, rutin and naringin (Sigma-Aldrich).

\section{Free flavonoids}

A Hypersil ODS HP column of $125 \mathrm{~mm}$ length and $4 \mathrm{~mm}$ internal diameter, $5 \mu \mathrm{m}$ particle size was used. The mobile phase was distilled water adjusted to $\mathrm{pH} 2.5$ with trifluoroacetic acid (A) and acetonitrile (B). The analysis was by gradient: T1 $0.10 \mathrm{~min}(85 \% \mathrm{~A})(15 \% \mathrm{~B})$; T2 $20 \mathrm{~min}(65 \% \mathrm{~A})(35 \% \mathrm{~B})$ and $\mathrm{T} 325 \mathrm{~min}(65 \%$ A), $(35 \% \mathrm{~B}), \lambda=254,316$ and $365 \mathrm{~nm}$, Column temperature $30^{\circ} \mathrm{C}$ and flow of $1 \mathrm{~mL} \mathrm{~min}{ }^{-1}$. Calibration curves were performed for standards: rutin, phorizine, quercetin, naringin, naringenin, floretin, galangin (SigmaAldrich).

The interpolations of all the extracts were calculated with ChemStation software $\subset$ Agilent Technologies, Inc. 2004. 
RESULTS AND DISCUSSION

2 By the application of photoacoustic spectroscopy and scanning electron microscopy for evaluate the effects of

3 UV-C radiation on bean seeds was found than there were differences between the control and treated samples.

4 According to PAS, there is a degradation of the seed due to the radiation, there were differences between the

5 photoacoustic spectra obtained for the control seeds $\left(\mathrm{T}_{0}=0 \mathrm{~min}\right)$ and for each one of the radiation treatments

6 applied $\left(\mathrm{T}_{1}=2, \mathrm{~T}_{2}=5, \mathrm{~T}_{3}=10\right.$ and $\left.\mathrm{T}_{4}=15 \mathrm{~min}\right)$ prior to sowing.

7 Figure 3a shows the optical absorption spectra where it is noted that the level of the photoacoustic signal

8 decreases with the increase of the radiation time of the bean seed (Oti). Note that the control seeds presented

9 the highest photoacoustic signal intensity level when compared with the spectra obtained from the seeds treated 10 with UV-C.

11 The higher changes were obtained in the phenolic and flavonoid acids absorption band, at the lowest 12 wavelenght, mainly in the absorption band of $270-450 \mathrm{~nm}$. It is observed that after $15 \mathrm{~min}$ of UV-C treatment 13 of the bean seed, the maximum absorption region tends to disappear. The photoacoustic signal shows the 14 maximum absorption in the UV region (A, B and C) according to the range of the photoacoustic absorption 15 spectrum obtained $(270-750 \mathrm{~nm})$.

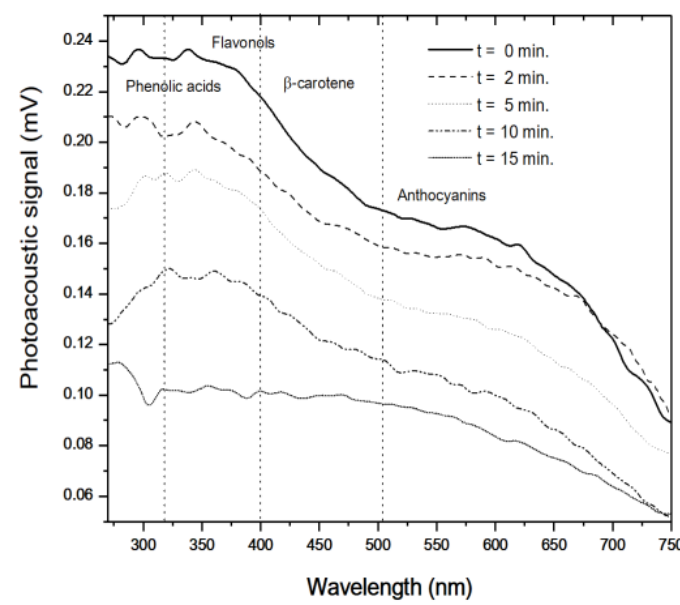

a)

Figure 3 Spectra of optical absorption obtained by PAS in control seeds (without UV-C radiation) and seeds treated with UV-C at 2, 5, 10 and 15 min: a) Photoacoustic signal b) Optical absorption coefficient ( $\beta$ ) and optical penetration length $\left(l_{\beta}\right)$ as a function of wavelength for seed samples.

Table 1 (Section a) shows the averages values of the photoacoustic signal (PA) obtained by PAS at different wavelengths for each one of the seed groups treated with UV-C. It was found, significant statistically differences $p \leq 0.05$ in the signal PA value at the different wavelength of the seeds treated, from $\lambda_{280}-\lambda_{430}$, that covers the ultraviolet region $(280-400 \mathrm{~nm})$; note that from $\lambda_{445}$, there were no significant statistical differences. 
1 It is observed that the absorption region of $280-430 \mathrm{~nm}$, significant statistical differences were found in the wavelengths of 280, 295, 310, 325, 340, 355, 370, 385, 400, 415 and $430 \mathrm{~nm}$. Being the maximum decrease in

3 the level of photoacoustic signal at the wavelengths of 295 and $340 \mathrm{~nm}$, there being a percentage of decrease of $458.33 \%$.

5 In the range of $\lambda_{280}-\lambda_{430}$, the percentage of decrease in the value of maximum intensity of photoacoustic signal 6 (control seeds) and the lowest value obtained in seeds $\mathrm{T}_{4}(15 \mathrm{~min})$ varied between 52 and $58 \%$. The higher 7 decrease in the photoacoustic signal was found in the UV region range. For wavelength values above $430 \mathrm{~nm}$, 8 a variation between the maximum and minimum photoacoustic signal value between 40 and $50 \%$ was obtained. 9 In this way, significant changes in the photoacoustic absorption spectra are related, due to the changes in the bean seed produced by the different radiation times applied in the bean seed.

11 Other authors evaluating milk powder by photoacoustic spectroscopy found changes in optical absorption 12 spectra due to different times of UV-C radiation. They related the optical absorption spectra with changes in 13 their oxidation levels (Dóka et al. 2000). In this research, is demonstrated that the content of secondary 14 metabolites such as phenolic acids and flavonoids are modified in seedlings from seed radiated by UV-C light. 15 Then, there is a decrease in the level of intensity of the photoacoustic signal. Since there is a relationship 16 between the level of the photoacoustic signal and the presence of secondary metabolites in the bean seeds, 17 which in bean seeds has been reported by other authors (Reynoso et al., 2007). If the photoacoustic signal level 18 is increased, it is because there are more chromophores associated at those wavelengths. The chromophores 19 would be the secondary metabolites present in the bean seed, which are affected by UV-C radiation. Figure $3 \mathrm{~b}$ represents the spectra of the optical absorption coefficient and the optical penetration length. It is observed that the highest values of $\beta$ correspond to the spectra with the highest level of PA signal; it was the 22 spectrum corresponding to the control seeds (without radiation). The bean seeds were thermally thick, which 23 means that $l_{s} / \mu_{s}=l_{s} /(\alpha / \pi f)^{1 / 2}=577 \gg 1$. By using the eq. 1 , were calculated $\beta$ and $l_{\beta}$. Figure $3 \mathrm{~b}$ shows the 24 optical absorption coefficient $(\beta)$ and optical penetration length $\left(l_{\beta}\right)$, as a function of the wavelength. The sample 25 average thickness $l_{s}=5.24 \mathrm{~mm} \pm 0.5$, according to the measurements of 100 seeds made by digital micrometer. 26 It is possible to observe that bean seeds are optically opaque in the 270 to $750 \mathrm{~nm}$ range, which means that $l_{\beta}<$ $27 l_{s}$ for all wavelengths and treatments applied to the seeds in the different radiation times UV-C $(0,2,5,10$, and $2815 \mathrm{~min}$ ). Fulfilling this condition since the values of the optical penetration length were lower than $1.2 \mathrm{~mm}$. 29 Also, it is observed that the optical penetration length increases as the radiation time of the seed increases for 30 the entire range of wavelength evaluated $(270-750 \mathrm{~nm})$.

32 The $l_{\beta}$ values decrease towards the ultraviolet region; the control seeds had the lowest optical penetration values. 33 It was found that to the higher degradation of the bean seed, the penetration length increases in the UV-A region 34 (320-400 nm) and with the tendency to decrease toward the UV-B (280-320 nm) and UV-C (200-280) nm. The 35 portion of the UV-C spectrum that is observed in Figure 3b, is the corresponding to $270-280 \mathrm{~nm}$. 
1 The value of the optical penetration length of the control seeds and those radiated at the different times $\left(\mathrm{T}_{1}, \mathrm{~T}_{2}\right.$,

$2 \mathrm{~T}_{3}$ and $\mathrm{T}_{4}$ ) varied from $0.22-0.65 \mathrm{~mm}$, at wavelength $270 \mathrm{~nm}$, corresponding to the UV-C range. According to

3 the trend of the curve, these values tend to decrease towards the wavelength value of $254 \mathrm{~nm}$ (maximum peak

4 of UV-C lamps). The value in the control seeds is lower and the higher penetration value corresponds to the

5 case of the seeds treated with UV-C for $15 \mathrm{~min}$, which is the maximum time of exposure of the seed to radiation

6 in this study; also, showed the higher degradation to this time of radiation $\left(\mathrm{T}_{4}\right)$. It should be mentioned that the

7 thermal diffusion length $\left(\mu_{s}=0.009 \mathrm{~mm}\right)$ is smaller than the optical penetration length.

8

9 In this investigation it was found that the degradation of the bean seed did not cause a decrease in the 10 physiological quality of the seed; expressed through germination, length and dry weight of seedlings. Variables

11 which, when compared with control, did not find significant statistical differences ( $p \leq 0.05$ ) (Table 1-Section

12 b). Although there is a tendency to increase and then decrease in the germination of seeds irradiated by 10 and

$1315 \mathrm{~min}$, respectively. The results show that PAS is sensitive to detect changes in bean seed, observed as a color

14 degradation in the seed itself. These changes were verified in this investigation, through the scanning electron 15 microscopy.

16

17 
1 Table 1 Averages of parameters obtained of seeds and seedlings of bean a) level of photoacoustic signal obtained by PAS at different wavelengths b)

2 germination variables of seedlings from treated seed.

3

a. Photoacoustic signal at different wavelengths b. Variables of seed germination

$\begin{array}{ccccccccccccccccc}\text { Tratment } & \lambda_{280} & \lambda_{295} & \lambda_{310} & \lambda_{325} & \lambda_{340} & \lambda_{355} & \lambda_{370} & \lambda_{385} & \lambda_{400} & \lambda_{415} & \lambda_{430} & \lambda_{445} & \lambda_{460} & \lambda_{475} & \text { G } & \text { TW }\end{array}$

4

5

\begin{tabular}{|c|c|c|c|c|c|c|c|c|c|c|c|c|c|c|c|c|c|}
\hline $\begin{array}{l}\text { 0) Control } \\
\text { (0) }\end{array}$ & $0.23 a$ & $24 a$ & $0.23 a$ & $0.23 a$ & $0.24 a$ & $0.23 a$ & $0.23 a$ & $0.22 a$ & 0.21 & $0.20 a$ & $0.19 a$ & $0.19 a$ & $0.18 a$ & $0.18 a$ & $86 a$ & $2.41 a$ & $9.48 a$ \\
\hline 1) 2 & $0.21 b$ & $0.21 b$ & $0.21 \mathrm{ba}$ & $0.20 \mathrm{ba}$ & $0.21 \mathrm{ba}$ & $0.20 \mathrm{a}$ & $0.20 a$ & $0.19 a$ & $0.19 \mathrm{ba}$ & $0.18 \mathrm{ba}$ & $0.17 \mathrm{ba}$ & $0.17 \mathrm{ba}$ & $0.16 \mathrm{ba}$ & $0.16 \mathrm{ba}$ & $80 a$ & $2.51 a$ & $9.9 a$ \\
\hline 2) 5 & $0.17 c$ & $0.18 c$ & $0.19 b$ & $0.19 b c$ & $0.19 b c$ & $0.19 \mathrm{ba}$ & $0.18 \mathrm{ba}$ & $0.18 \mathrm{ba}$ & $0.17 \mathrm{ba}$ & $0.16 \mathrm{ba}$ & $0.15 \mathrm{bac}$ & $0.15 \mathrm{bac}$ & $0.14 \mathrm{bac}$ & $0.14 \mathrm{ba}$ & $75 a$ & $1.86 a$ & $9.6 a$ \\
\hline 3) 10 & $0.13 d$ & $0.14 d$ & $0.15 c$ & $0.15 c$ & $0.15 c$ & $0.15 b c$ & $0.15 b c$ & $0.14 b c$ & $0.14 b c$ & $0.13 b c$ & $0.13 b c$ & $0.12 b c$ & $0.12 \mathrm{bc}$ & $0.11 \mathrm{ba}$ & $87 a$ & $1.95 a$ & $10.3 a$ \\
\hline 4) 15 & $0.11 \mathrm{e}$ & $0.10 \mathrm{e}$ & $0.10 \mathrm{~d}$ & $0.10 \mathrm{~d}$ & $0.10 \mathrm{~d}$ & $0.10 c$ & $0.10 c$ & $0.09 c$ & $0.10 c$ & $0.10 c$ & $0.09 c$ & $0.09 c$ & $0.09 c$ & $0.09 b$ & 79a & $2.25 a$ & $11.06 a$ \\
\hline LSD (0.05\%) & 0.02 & 0.03 & 0.03 & 0.03 & 0.04 & 0.04 & 0.05 & 0.05 & 0.05 & 0.06 & 0.06 & 0.06 & 0.06 & 0.06 & 20.9 & 0.464 & 0.608 \\
\hline Media & 0.171 & 0.175 & 0.173 & 0.174 & 0.175 & 0.174 & 0.172 & 0.168 & 0.164 & 0.158 & 0.152 & 0.147 & 0.144 & 0.141 & 81.4 & 2.20 & 28.91 \\
\hline Significance & $0.0002^{* *}$ & $0.0007^{* *}$ & $0.0015^{* *}$ & $0.0033^{* *}$ & $0.0045^{* *}$ & $0.0087^{* *}$ & $0.01^{*}$ & $0.01^{*}$ & $0.01^{*}$ & $0.03^{*}$ & $0.05^{\star}$ & $0.06 \mathrm{~ns}$ & $0.08 \mathrm{~ns}$ & $0.10 \mathrm{~ns}$ & $0.7 \mathrm{~ns}$ & $0.3^{*}$ & $0.01^{*}$ \\
\hline C.V. (\%) & 3.68 & 5.26 & 6.55 & 7.61 & 8.62 & 9.78 & 10.29 & 10.49 & 11.55 & 12.8 & 14.48 & 15.38 & 16.16 & 16.93 & 19.16 & 27.64 & 0.48 \\
\hline$R^{2}$ & 0.99 & 0.99 & 0.98 & 0.97 & 0.97 & 0.96 & 0.96 & 0.96 & 0.95 & 0.94 & 0.93 & 0.92 & 0.91 & 0.90 & 0.25 & 0.68 & 0.98 \\
\hline
\end{tabular}

6 Means with the same letter in a column are statistically equal (LSD (Lows significant differences) , 0.05); $\lambda$-wavelength, $\left(\lambda_{280}, \lambda_{295}, \lambda_{310} \ldots \ldots \ldots \lambda_{475}\right)$

7 represent the photoacoustic signal at the wavelengths of 280, 295, 310, 325, 340, 355, ... 445, 460 and $475 \mathrm{~nm}$. TW: Total weight, G: Germination percentage

8 and L: seedling length. 


\section{Analysis of micrographs}

2 Figure 4 shows micrographs of control bean seed $\left(\mathrm{T}_{0}=0 \mathrm{~min}\right)$ and exposed with UV-C light at different 3 radiation times $\left(\mathrm{T}_{1}=2, \mathrm{~T}_{2}=5, \mathrm{~T}_{3}=10\right.$ and $\mathrm{T}_{4}=15 \mathrm{~min}$ ), taken at 5000x from the surface of beans (first row) 4 and 1000x in half of the bean seed (second and third row). In the image of the surface of the bean seed (first

5 row) it is observed that the treatment with UV-C at different times affected significantly, because there is evidence of surface rupture notoriously observed in $\mathrm{T}_{3}=10$ and $\mathrm{T}_{4}=15 \mathrm{~min}$. In the second row it is observed that for the control sample $\left(\mathrm{T}_{0}\right)$, the cell wall (sclereides), mainly cellulose, hemicellulose and lignin are found attached to the testa and body of the cotyledon. As the dose of UV-C increases, the presence of micro-holes in the testa, and detachment of the sclereids of the cotyledon is evident. In the $\mathrm{T}_{4}$ treatment, changes of structural conformation are clearly shown. Regarding the change of the starches (third row), when applying higher radiation treatments to the seed $\left(\mathrm{T}_{3}\right.$ and $\left.\mathrm{T}_{4}\right)$, the starch granules are compacted, such that the cell wall of the cotyledon swells.
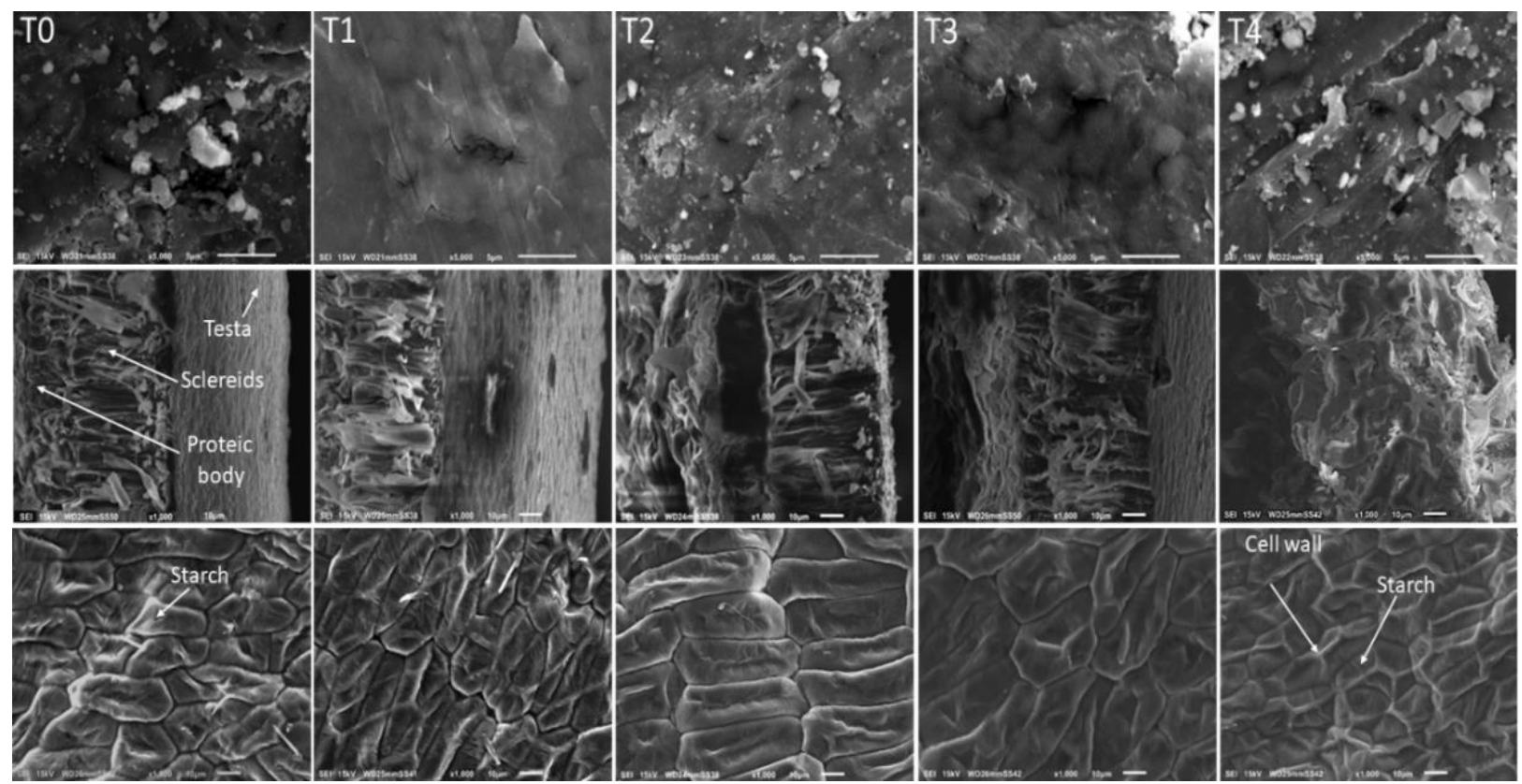

Figure 4 Micrographs of control bean seed $\left(\mathrm{T}_{0}=0 \mathrm{~min}\right)$ and exposed with UVC light at different radiation

$$
\text { times }\left(\mathrm{T}_{1}=2, \mathrm{~T}_{2}=5, \mathrm{~T}_{3}=10 \text { and } \mathrm{T}_{4}=15 \mathrm{~min}\right) \text {, }
$$

16 Torres (1985) mentions that the cell wall of the cotyledon is mainly composed of cellulose, hemicellulose and

17 pectic substances, which bind to most cells and provide the physical resistance of the tissue. Figure 4 could

18 assume that the network that holds the starches radiated at the highest dose contains mostly pectic substances

19 because it shows a gel texture, more flexible than the cell wall of the "testa". Singh et al. (2013) found that the

20 stability of cell walls components and the rearrangement of starch granules in cells can affect the free access of

21 amylolitic enzymes during digestion (when beans are used for consumption), since the starch granules enclosed

22 within the intact cells are compacted. Hussain et al. (2014), reported that by applying gamma radiation to bean starch the proportions of rapidly digestible starch were increased. 
1 Likewise, Hyun-Jung et al. (2014) and Gani et al. (2012) showed that by applying gamma radiation the 2 degradation of amylose and amylopectin is induced, which alters the morphological, crystalline and 3 physicochemical properties of starch. Starches in their native form are sometimes not functional for some 4 processes. However, when applying UV-C radiation, the bean starches and the cell wall of the cotyledon undergo changes, as was demonstrated in the present investigation. These changes, as mentioned by other authors, could modify their functional properties, which would benefit the food industry as an additive. The advantage of applying UV-C could be in which does not induce a significant increase in temperature, minimum preparation of the sample, without dependence on some type of catalysis (Farkas, 1998), as well as a low cost.

For the condition of bean as a seed and not as grain of consumption, UV-C radiation has been reported with stimulating effects on germination, both stimulant and inhibitory effects (Urban et al., 2016). As the case described by Lazim and Nasur (2017) who treated sorghum seed (Sorghum bicolor L.) with UV-C for different times $(0,30$ and $60 \mathrm{~min})$ did not find significant effects on germination percentage and the length of the seedling roots. While showed a significantly negative impact on speed germination, seedling length and the number of leaves. Similar results in the length of the seedlings germinated were found in black beans by (Guajardo-Flores et al., 2014), who did not find significant statistical differences in the length of the seedlings; however, changes were found in the speed of germination.

In the present investigation, the length of the seedlings varied in a range of 9.48 to11.06 cm after 11 days of germination; under the conditions in which the experiment was elaborated and it did not have statistical differences. In this way the physiological quality is not modified, within the radiation time interval used in this investigation. It is possible to note (Table 1b) that the smallest and the maximum length of the seedlings were from control seed and radiated for $15 \mathrm{~min}$.

The emergent physical methods have been reported as pre-sowing treatments harmless for the environment; but these treatments must be applied with suitable parameters in order to improve the seed vigour and ensure better plant development at later stages (Hernández et al. 2009). In this way is necessary to explore the optimal radiation parameters: exposure time, the radiation intensity, the power of the light source, the radiation regimes, etc. Likewise, the conditions and location of the seeds: the separation distance of them respect to the light, the placement (on moving or fixed), the container on which it is placed, etc. It is important use the appropriate treatment and conditions to produce the expected beneficial result.

In the present investigation, there were no significant differences between the treatments applied, but there was a tendency to reduce the germination at $15 \mathrm{~min}$. Other authors with a longer exposure time (up to $180 \mathrm{~min}$ ) found a stimulating effect on wheat seeds, improving germination (Rupiasih and Vidyasagar 2016). Other studies also indicated a tendency to decrease and increase the percentage of germination, according to the times of exposure to UV-C radiation. Neelamegam and Sutha (2015), found a decrease in germination and then an 
increase at 5 and 60 min of exposure in groundnut seed (Arachis hypogaea L.) by UV-C, respectively at 10 days of germination.

Depending on the genotype and characteristics of the seed, the effect will be produced. In the present investigation, it is observed that germination tends to decrease $\left(\mathrm{T}_{2}\right)$ and then to present a slight increase $\left(\mathrm{T}_{3}\right)$ and then decrease again $\left(\mathrm{T}_{4}\right)$. In experiments carried out with sunflower seeds by Torres et al. (1991) it was reported that the UV-C radiation between the time of 5-60 min reduced the percentage of normal seedlings. Other authors have found that depending on the genotype of red bean seeds are the effects obtained on germination (Peykarestan and Seify 2012).

According to Solecka (1997), exposure of plant tissues to UVC increases the concentration of reactive oxygen species (ROS), which induces seed germination (Guajardo-Flores et al. 2014). UV-C irradiation treatment on agricultural seeds has generally been reported promoted the seed germination. In experiments carried out on Mung bean (Vigna radiata) seeds, they reported an increase in germination at times of exposure to UV-C radiation of 2, 4 and $6 \mathrm{~h}$ (Hamid and Jawaid 2011). Although there were no significant differences in germination in this investigation, a tendency to be modified by UV-C was found depending on the time of exposure to radiation to this type of bean seed used.

In the case of the dry weight of the seedlings from the radiated seed and control (without radiation) (Table 1b), it was found that the highest weight was obtained in the control seedlings and those radiated at 2 min. While the lowest weight was for seedlings from seed radiated for $5 \min \left(\mathrm{T}_{2}\right)$.

In a separate way the weight of root and foliage; it was found that at two minutes the foliage weight tends to increase, with a tendency to decrease at $5 \mathrm{~min}$ and then increase again at $10 \mathrm{~min}$. In the case of the weight of the roots, a slight tendency to decrease was obtained as the pre-sowing UV-C radiation time increases. Also, other authors have indicated a modification of the weight of the components of seedlings (root and foliage). Siddiqui et al. (2011) observed increment in shoot weight when seeds of groundnut (Arachis hypogaea L.) and mung bean (Vigna radiata L.) were treated with UV-C for 10, 15, 30 and $60 \mathrm{~min}$. Biomass as a measure of growth makes it possible to know the distribution of dry matter among the various organs, as well as to estimate the magnitude of the demand for assimilates (Hunt 1990). In the different times exposed to UV-C radiation there were significant differences with respect to the dry weight accumulated in roots and foliage (Figure 5). 


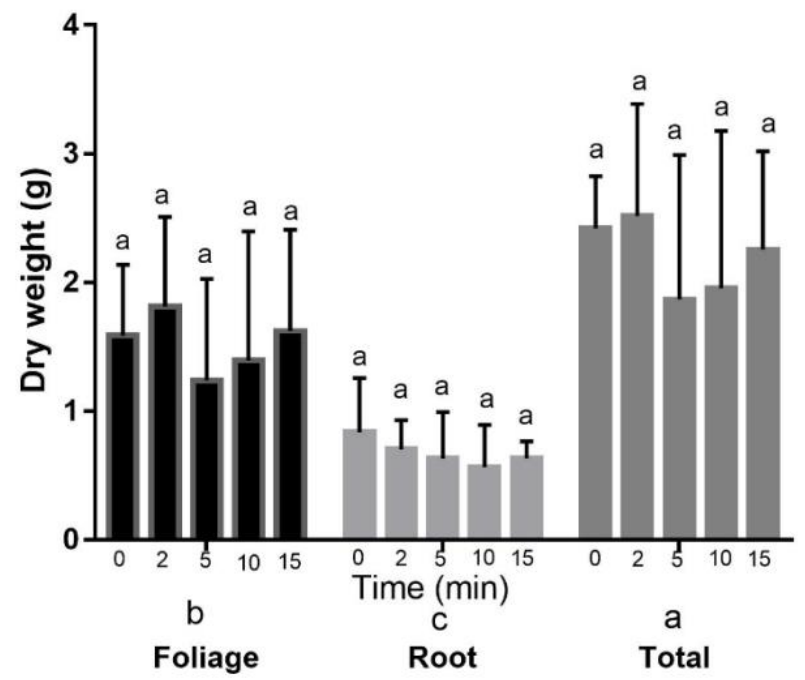

Figure 5. Cumulative dry weight of seed bean seedlings exposed to different times of shortwave ultraviolet radiation. Different letters mean that there are significant differences according to the average comparisons (Tukey $\alpha=0.05$ ). Time refers to different minutes of UV-C irradiation $\left(T_{0}, T_{1}, T_{2}, T_{3}\right.$ and $\left.T_{4}\right)$.

Other applications of UV-C radiation on agricultural seeds before sowing, is the improvement of sanitary quality, due to its sterilizing and antifungal effects (Dawar 2013; Ferreira 2011; Santos 2013; Siddiqui et al. 2011; Rodriguez et al. 2012). UV-C radiation has been used in the control of fungal growth of castor bean seeds (Dawar 2013). In this way it is important to define the appropriate radiation times because UV-C radiation degrades the seed and could modify (positive, null or negative) their physiological quality variables.

\section{Phenolic compounds}

The phenolic acids identified in the seedling from bean seeds treated pre-sowing by UVC and control (without radiation) were similar between root and foliage: gallic, chlorogenic, syringic, vanillinic, p-hydroxybenzoic, caffeic, ferulic , p-cumaric ; to exception of the ferulic acid which was not identified in foliage.

The phenolic acid most abundant in seedling from seed control (without radiation) was chlorogenic (18.7 $\mu \mathrm{g} / \mathrm{mL})$, followed by p-cumaric $(2.8554 \mu \mathrm{g} / \mathrm{mL})$ and caffeic $(2.72 \mu \mathrm{g} / \mathrm{mL})$. In the case of foliage, the most abundant were caffeic acid $(78.27 \mu \mathrm{g} / \mathrm{mL})$, followed by chlorogenic $(18.71 \mu \mathrm{g} / \mathrm{mL})$.

The phenolic acids of the bean $(O t i)$ seedlings from of seed treated by UV-C for different exposure times $(0,2$, $5,10$ and $15 \mathrm{~min})$ showed significant statistical differences $(P \leq 0.05)$ in both roots and foliage. There were significant differences according to the treatment in p-hydroxybenzoic, syringic, caffeic and ferulic of the roots (Table 2). The highest concentrations of p-hydroxybenzoic acid $(2.26 \mu \mathrm{g} / \mathrm{mL})$, syringic acid $(1.61 \mu \mathrm{g} / \mathrm{mL})$ were 
1 obtained at $10 \mathrm{~min}$ of radiation exposure of the seed prior to sowing. While at 15 minutes of exposure to UV-C

2 radiation was found the highest concentration of phenolic acids: caffeic acid (10.6 $\mu \mathrm{g} / \mathrm{mL})$ and ferulic acid (2.6

$3 \mu \mathrm{g} / \mathrm{mL})$.

4

5 Table 2. Concentration of phenolic acids in seedlings of bean seeds exposed at different times of shortwave

6 ultraviolet radiation.

\begin{tabular}{|c|c|c|c|c|c|c|c|c|}
\hline $\begin{array}{l}\text { Phenolic acids } \\
(\mu \mathrm{g} / \mathrm{mL})\end{array}$ & $\begin{array}{l}\text { a) Roots } \\
\mathrm{T}_{0} \\
\text { (Control) }\end{array}$ & $\mathrm{T}_{1}$ & $\mathrm{~T}_{2}$ & $\mathrm{~T}_{3}$ & $\mathrm{~T}_{4}$ & DMS & $\mathrm{R}^{2}$ & Mean \\
\hline \multicolumn{9}{|l|}{ Gallic acid } \\
\hline & $0.89 \mathrm{a}$ & $0.68 \mathrm{a}$ & $38.62 \mathrm{a}$ & $9.05 \mathrm{a}$ & 0a & 43.144 & 0.79030 & 9.848445 \\
\hline 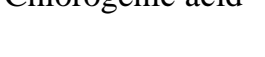 & $18.7 \mathrm{a}$ & $10.054 \mathrm{a}$ & $10.086 \mathrm{a}$ & $5.241 \mathrm{a}$ & $8.886 \mathrm{a}$ & 17.487 & 0.673174 & 10.59106 \\
\hline syrmic acid & $0 \mathrm{~b}$ & $0 \mathrm{~b}$ & $\mathrm{Ob}$ & $1.61 \mathrm{a}$ & $0 \mathrm{~b}$ & 1.0947 & 0.91773 & 0.322246 \\
\hline Vanillinic acid & $0 \mathrm{a}$ & $0 \mathrm{a}$ & $1.4177 \mathrm{a}$ & $0 \mathrm{a}$ & $0 \mathrm{a}$ & 3.5968 & 0.44444 & 0.283534 \\
\hline $\begin{array}{l}\text { p-hydroxybenzoic } \\
\text { acid }\end{array}$ & $0 \mathrm{c}$ & $0 \mathrm{c}$ & $2.1 \mathrm{~b}$ & $2.26 \mathrm{a}$ & $0 \mathrm{c}$ & 0.1058 & 0.9999 & 0.871215 \\
\hline Caffeic acid & $2.72 \mathrm{a}$ & $3.1 \mathrm{a}$ & $\mathrm{Ob}$ & $0 \mathrm{~b}$ & $10.684 a$ & 9.8393 & 0.83602 & 3.300694 \\
\hline Ferulic acid & $0 \mathrm{c}$ & $0 \mathrm{c}$ & $0 \mathrm{c}$ & $1.60 \mathrm{~b}$ & $2.6826 a$ & 0.4097 & 0.995743 & 0.857896 \\
\hline p-Coumaric acid & $2.8554 \mathrm{a}$ & $1.5117 \mathrm{a}$ & $0.6051 \mathrm{a}$ & $0.0763 \mathrm{a}$ & $0 \mathrm{a}$ & 3.9911 & 0.69776 & 1.009725 \\
\hline & b) Foliage & & & & & & & \\
\hline Gallic acid & $0 \mathrm{a}$ & $0 \mathrm{a}$ & $0 \mathrm{~b}$ & $6.65 a$ & $0 \mathrm{~b}$ & 0.2243 & 0.999780 & 1.331945 \\
\hline Chlorogenic acid & $18.71 \mathrm{a}$ & $0 \mathrm{c}$ & $6.037 \mathrm{c}$ & $9.682 \mathrm{~b}$ & $23.74 \mathrm{a}$ & 12.261 & 0.94020 & 11.63444 \\
\hline Syringic acid & $0 \mathrm{~b}$ & $3.5091 \mathrm{a}$ & $0 \mathrm{~b}$ & $0.813 b$ & $0 \mathrm{~b}$ & 1.0323 & 0.97825 & 0.792902 \\
\hline Vanillinic acid & $0 \mathrm{~b}$ & $0 \mathrm{~b}$ & $0 \mathrm{~b}$ & $0.838 \mathrm{a}$ & $0 \mathrm{~b}$ & 0.0196 & 0.9999 & 0.167695 \\
\hline $\begin{array}{l}\text { p-hydroxybenzoic } \\
\text { acid }\end{array}$ & $\mathrm{Ob}$ & $0 \mathrm{~b}$ & $0 \mathrm{~b}$ & $2.237 \mathrm{a}$ & $0 \mathrm{~b}$ & 0.0149 & 0.9999 & 0.447427 \\
\hline Caffeic acid & $78.27 \mathrm{~b}$ & $0.317 \mathrm{~b}$ & $5.01 \mathrm{a}$ & $4.77 \mathrm{a}$ & $6.755 \mathrm{a}$ & 2.0191 & 0.98061 & 3.530364 \\
\hline Ferulic acid & $0 \mathrm{~b}$ & $0 \mathrm{~b}$ & $7.559 a$ & $6.813 \mathrm{a}$ & $7.893 \mathrm{a}$ & 1.5868 & 0.99417 & 0.004453 \\
\hline
\end{tabular}

7 DMS is significant minimum difference. The different letters indicate significant differences between the

8 Tukey means test $(\alpha=0.05) . T_{0}, T_{1}, T_{2}, T_{3}$ and $T_{4}$ equals to radiation exposure time of the pre-sowing seed

$9: 0,2,5,10$ and 15 min of radiation UV-C.

10

11 For phenolic acids of foliage there were significant differences in gallic acid, chlorogenic, syringic acid,

12 vanillinic, p-hydroxybenzoic, caffeic acid and p-cumaric. Being the highest concentration at the time of $10 \mathrm{~min}$

13 for: gallic acid $(6.65 \mu \mathrm{g} / \mathrm{mL})$, vanillinic $(0.83 \mu \mathrm{g} / \mathrm{mL})$ and p-hydroxybenzoic acid $(2.23 \mu \mathrm{g} / \mathrm{mL})$. While seeds 
radiated for $15 \mathrm{~min}$ produced seedlings with higher concentration levels of: chlorogenic acid $(23.74 \mu \mathrm{g} / \mathrm{mL})$, p-cumaric $(7.8 \mu \mathrm{g} / \mathrm{mL})$ and caffeic $(6.75 \mu \mathrm{g} / \mathrm{mL})$. Studies carried out by other authors have coincided that the application of UV radiation can induce the accumulation of phenolic compounds in legume seedlings. Shetty et al. (2002) exposing seeds of faba beans (Vicia faba) to UV-C light for 2, 5 and $10 \mathrm{~h}$ and germinated for 8 days in the dark indicated an increase in nutraceutically-relevant phenolic metabolites with enhanced antioxidant activity in response to UV stress.

In our results there was modification of phenolic acids, which in general, increased their concentration with the increase of exposure times to UV-C radiation; without stress condition. Aboul et al. (2014), evidenced that the Green bean seed treatment with UV-C improved plant growth under stressful and non-stressful conditions. Growth variables were modified through exposure times of 30 and 60 minutes; e.g. the authors found significantly enhanced shoot fresh weight of grown plants by 33.9 and $82.5 \%$, respectively. In other studies, applying UV-C in fruit epidermal tissue has been shown that UV light induces the accumulation of UV absorbing flavonoids and other phenolics compounds (Strack 1997).

\section{Flavonoids}

Regarding to phenolic compounds of the flavonoid type, it can be observed (Table 3), that the flavonoids identified in roots of control and radiated seedlings were: rutin, phorizine, quercetin, naringenin, floretin, galangin, naringin, hespiridin, apigenin-7-0-glucoside. In foliage there were similars flavonoids identified in the roots, except the phloretin that was not identified. The flavonoid most abundant in this type of bean seed (Oti) was Phlorizin $(460 \mu \mathrm{g} / \mathrm{mL})$.

Flavonoids of the seedlings from of seed treated by UV-C for different exposure times (0, 2, 5, 10 and $15 \mathrm{~min})$ showed significant statistical differences $(P \leq 0.05)$ in both root and foliage. It is possible observe that there were significant statistical differences in the case of the flavonoids of the seedling roots for rutin, phorizine, quercetin, galangin, and apigenin-7-0-glucoside. The highest concentrations of flavonoids: Phlorizin (737.1 $\mu \mathrm{g} / \mathrm{mL})$, quercetin $(39.7 \mu \mathrm{g} / \mathrm{mL})$, galangin $(25.4 \mu \mathrm{g} / \mathrm{mL})$, and apigenin-7-0-glucoside $(9.95 \mu \mathrm{g} / \mathrm{mL})$ were found in the seedling roots whose seed was treated during $15 \mathrm{~min}$. In the case of flavonoids rutin $(3.4 \mu \mathrm{g} / \mathrm{mL})$ was found the maximum concentration in the radiation time of the seed for 5 min (Table 3-section a).

In relation to flavonoids of foliage it is possible observe that there were significant differences in phorizine, quercetin, naringenin, galangin, hespiridin and apigenin-7-0-glucoside. Being, the highest concentration obtained in the foliage of the seedlings of the control seeds (without radiation pre-sowing). For all cases, UV$\mathrm{C}$ radiation caused a decrease of this type of flavonoids in the foliage of the seedlings (Table 3-section b) 
3 Table 3 Concentration of flavonoids in bean seedlings from seeds radiated by UV-C: a) Roots, b) Foliage.

\begin{tabular}{|c|c|c|c|c|c|c|c|c|}
\hline $\begin{array}{l}\text { Flavonoids } \\
(\mu \mathrm{g} / \mathrm{mL})\end{array}$ & $\begin{array}{l}\text { T0 } \\
\text { (Control) }\end{array}$ & $\begin{aligned} & \text { a) } \mathbf{F} \\
\mathrm{T} 1 & \end{aligned}$ & oot & T3 & $\mathrm{T} 4$ & DMS & $\mathrm{R}^{2}$ & Media \\
\hline Rutin & $1.9^{\mathrm{a}}$ & $0^{\mathrm{b}}$ & $3.4^{\mathrm{a}}$ & $0^{\mathrm{b}}$ & $1.9^{\mathrm{a}}$ & 1.5 & 0.958 & 1.45 \\
\hline Phlorizin & $460^{c}$ & $398^{c}$ & $553.75^{\mathrm{b}}$ & $269.6^{\mathrm{d}}$ & $737.1^{\mathrm{a}}$ & 77.24 & 0.992 & 483.7400 \\
\hline quercetin & $0^{\mathrm{b}}$ & $0^{\mathrm{b}}$ & $0^{\mathrm{b}}$ & $0^{\mathrm{b}}$ & $39.7^{\mathrm{a}}$ & 4.3294 & 0.997 & 7.936310 \\
\hline Naringenin & $26.3^{\mathrm{a}}$ & $0^{\mathrm{a}}$ & $4.74^{\mathrm{a}}$ & $0^{\mathrm{a}}$ & $10.9^{\mathrm{a}}$ & 52.792 & 0.526 & 8.386 \\
\hline Phloretin & $1.2594^{\mathrm{a}}$ & $0^{\mathrm{a}}$ & $0^{\mathrm{a}}$ & $1.6884^{\mathrm{a}}$ & $0^{\mathrm{a}}$ & 3.9597 & 0.525 & 0.589561 \\
\hline Galangin & $17.32^{\mathrm{b}}$ & $7.52^{\mathrm{d}}$ & $15.85^{\mathrm{b}}$ & $11.5^{\mathrm{c}}$ & $25.48^{\mathrm{a}}$ & 4.608 & 0.982 & 15.53901 \\
\hline Naringin & $185.8^{\mathrm{a}}$ & $48.2^{\mathrm{a}}$ & $41.57^{\mathrm{a}}$ & $39.82^{\mathrm{a}}$ & $26.64^{\mathrm{a}}$ & 190.1 & 0.756 & 68.41133 \\
\hline \multirow{3}{*}{$\begin{array}{l}\text { Hespiridin } \\
\text { Apigenin-7-0- } \\
\text { glucoside }\end{array}$} & $198.7^{\mathrm{a}}$ & $185.69^{\mathrm{a}}$ & $139.24^{\mathrm{a}}$ & $117.15^{\mathrm{a}}$ & $195.21^{\mathrm{a}}$ & 214.8 & 0.430 & 167.2037 \\
\hline & $0^{\mathrm{c}}$ & $5.4151^{b}$ & $4.9966^{\mathrm{b}}$ & $3.57^{\mathrm{b}}$ & $9.95^{\mathrm{a}}$ & 0.0022 & 0.9857 & 4.788967 \\
\hline & \multicolumn{7}{|c|}{ b) Foliage } & \\
\hline Rutin & $2.37^{\mathrm{a}}$ & $0.9368^{\mathrm{a}}$ & $0.1305^{\mathrm{a}}$ & $0^{\mathrm{a}}$ & $0.4258^{\mathrm{a}}$ & 2.7431 & 0.760633 & 0.773029 \\
\hline Phlorizin & $532.9^{\mathrm{a}}$ & $515.1^{\mathrm{a}}$ & $247.2^{\mathrm{c}}$ & $411.2^{\mathrm{b}}$ & $268.4^{\mathrm{c}}$ & 62 & 0.991702 & 394.9824 \\
\hline Quercetin & $162^{\mathrm{a}}$ & $54.46^{\mathrm{b}}$ & $5.36^{\mathrm{b}}$ & $0^{\mathrm{b}}$ & $0^{\mathrm{b}}$ & 101.6 & 0.93561 & 44.39249 \\
\hline Naringenin & $3.53^{\mathrm{a}}$ & $1.02^{\mathrm{b}}$ & $1.89^{\mathrm{b}}$ & $13.0^{\mathrm{a}}$ & $0^{\mathrm{b}}$ & 10.506 & 0.865709 & 3.890745 \\
\hline Galangin & $18.41^{\mathrm{a}}$ & $12.1^{\mathrm{b}}$ & $3.8^{\mathrm{c}}$ & $13.48^{\mathrm{a}}$ & $10.18^{b}$ & 6.0233 & 0.952677 & 11.58393 \\
\hline Naringin & $0^{\mathrm{a}}$ & $66.85^{\mathrm{a}}$ & $28.14^{\mathrm{a}}$ & $32.90^{\mathrm{a}}$ & $0.76^{\mathrm{a}}$ & 79.045 & 0.757594 & 25.73127 \\
\hline Hespiridin & $249.32^{\mathrm{a}}$ & $82.75^{\mathrm{b}}$ & $0^{\mathrm{b}}$ & $1.67^{\mathrm{b}}$ & $11.27^{\mathrm{b}}$ & 163.66 & 0.915828 & 69.00097 \\
\hline $\begin{array}{l}\text { Apigenin-7-0- } \\
\text { glucoside }\end{array}$ & $11.646^{\mathrm{a}}$ & $2.162^{\mathrm{b}}$ & $2.79^{\mathrm{b}}$ & $1.189^{\mathrm{b}}$ & $1.454^{\mathrm{b}}$ & 5.187 & 0.948951 & 3.859616 \\
\hline
\end{tabular}

4 DMS is the least significant difference and the same letter are statistically equal (Tukey, $\mathrm{P} \leq 0.05$ ). $\mathrm{T}_{0}, \mathrm{~T}_{1}, \mathrm{~T}_{2}$,

$5 \mathrm{~T}_{3}$ and $\mathrm{T}_{4}$ equals to $2,5,10$ and 15 min of radiation $\mathrm{UV}-\mathrm{C}$.

6 In this way, this research demonstrates that by means of UV-C radiation, applied pre-sowing to the bean seed

7 (Oti), it is possible to modify phenolic compounds (phenolic acids and flavonoids) of the seedlings from the

8 radiated seeds. Similar results have been reported by Guajardo-Flores et al. (2014), who radiated the black bean

9 seed during $20 \mathrm{~h}$ in germination period, reporting higher accumulation of flavonoids during germination in

10 radiated seed. In this investigation, some of the flavonoids of the roots of the seedlings from radiated seed were

11 increased to 5 and 15 min of UV-C exposure.

12

13 As is known, secondary metabolites have a relevant role in the physiological and plant development processes,

14 included to stress responses and to the protection against pathogens (Katerova et al. 2013).

15 The results coincide with other authors who have detected the presence of flavonols, flavones and anthocyanins

16 in bean plants (Deckmyn et al. 1994). Especially the flavonoids are linked with regulatory mechanisms with

17 symbiosis of bacteria (M. A.W.B. and Phillips 1992). Coinciding the presence of naringin and naringenin in the

18 exudates of bean roots. 
1 Other authors have agreed on the effects of UV-C radiation, but in another type of biological sample. As in the 2 case of callus culture; e.g. in callus culture (Vitis vinifera L.) where a higher accumulation secondary 3 metabolites was reported (Cetin 2014). Other authors applying the UV-C in callus culture of Bacopa monnier 4 have suggested that UV-C radiation is a useful technique which can be used to enhance the accumulation of 5 phytochemicals (Meenashree et al. 2018).

7 Likewise, the effects due to UV-C on secondary metabolites in epidermal tissues of fruit have been evaluated.

8 In tomatoes irradiated by UV-C, significantly increased total phenolic content was described when were 9 compared treated and untreated samples (Bravo et al. 2012).

10

11

12

13

14

According to our findings it has been demonstrated that the seed treated with UV-C light is degraded as a function of the time of exposure to UV-C light, demonstrated through photoacoustic spectroscopy and scanning electron microscopy. But, the seeds radiated could produce seedlings with higher concentration of some secondary metabolites, as the flavonoid and phenolic acid type. These results could impact on different applications, in the seed: to activate defense mechanisms and improve germination. Other future applications could concentrate on the products consumed by the population, since they could modify the nutritional qualities of the products consumed and have better nutritional quality of them.

For this reason, several recent studies have examined the importance of UV-C radiation with regard to different quality parameters of treated plant foods, evaluating possible effects on their functional properties. A recognized advantage of applying UV-C is the capability to improve the nutraceutical properties of plant foods, and some studies have reported the possibility of increasing the antioxidant content through UV-C irradiation as a postharvest treatment. In this research, secondary metabolites were modified both in seed and in the seedling from radiated seed. Then, in the case of agricultural seeds, UV-C radiation could serve not only to improve physiological quality, but also physiological and nutritional, the latter being beneficial when the plant is consumed in the form of sprouts.

In this way, UV-C radiation on seeds produce their degradation as a function of the radiation time. It is possible that the UV-C light interacts with different structural levels of the seed and in this way to photostimulate chromophores that intervene in metabolic processes of the seed. Future applications should be optimized towards the most convenient method; in relation to the conditions of the seed, the characteristics of the seed itself as well as the expected effect produced by UV-C light.

\section{CONCLUSIONS}

Variations of the photoacoustic signal produced by bean seeds exposed to UV-C radiation during 2, 5, 10 and 15 minutes, have been measured within the spectral band $(270-400) \mathrm{nm}$. Based on scanning electron microscopy, it has been shown that the decrease of this signal is generated by the seeds' degradation, such that its maximum reduction from 0.24 to $0.10 \mathrm{mV}$ shows up at 295 and $340 \mathrm{~nm}$, after 15 minutes of exposure. As 
the UV-C radiation time increases from 2 to $15 \mathrm{~min}$, the morphological changes at the surface of the bean seeds exhibits micro-holes and detachment of the cotyledon sclereids. The phenolic acids and flavonoids of the bean seedlings of seeds treated by UV-C for different exposure times $(0,2,5,10$ and $15 \mathrm{~min})$ exhibit significant statistical differences $(\mathrm{P} \leq 0.05)$ in both roots and foliage. For both the roots and foliage, the highest concentration of phenolic acids has been found at 10 and 15 minutes, while for root flavonoids, it appears at 5 and 15 minutes.

\section{Acknowledgements}

I thank Dr. Estrada for providing the bean seed and Ing. Esther Ayala for the technical assistance at the Cinvestav Photothermal Techniques Laboratories. Claudia Hernandez thanks the support for SIP research projects.

\section{Conflict of Interest}

There is no conflict of interest in relation to the article presented. Taking into consideration that the author and the coauthors of the article mention that an original article is presented, not published and does not infringe any legal copyright, or any property right or any other right whatsoever.

\section{References}

Aboul Fotouh MM, Moawad FG, El-Naggar HA, El-Din MT, Eldeen HS (2014) Influence of sed treatment with UV-C on saline stress tolerance in green beans (Phaseolus vulgaris L.). Environ Sci 9:391-414.

Altieri MA (1994) Bases agroecológicas para una producción agrícola sustentable. Agricultura técnica 54: 371386.

Aladjadjiyan A, Kakanakova A (2008) Physical methods in agro-food chain. J Cent Eur Agric 9:789-794

Aladjadjiyan A (2012) Physical factors for plant growth stimulation improve food quality. Food productionapproaches, challenges and tasks 270 .

Alexieva V, Sergiev I, Mapelli S, Karanov E (2001) The effect of drought and ultraviolet radiation on growth and stress markers in pea and wheat. Plant Cell Environ 24:1337-1344.

Araújo SDS, Paparella S, Dondi D, Bentivoglio A, Carbonera D, Balestrazzi A (2016) Physical methods for seed invigoration: advantages and challenges in seed technology. Frontiers in plant science 7:646.

Baulcombe D, Crute I, Davies B, Dunwell J, Gale M, Jones J, Toulmin C (2009) Reaping the benefits: science and the sustainable intensification of global agriculture. The Royal Society.

Barta C, Kalai T, Hedig K, Vass I, Hedig E (2004) Differences in the ROS-generating efficacy of various ultraviolet wavelengths in detached spinach leaves. Funct Plant Biol 31:23-28. doi:10.1071/FP03170 
Bilia AR, Salvini D, Mazzi G, Vincieri FF (2000) Characterization of Calendula Flower, Milk-Thistle Fruit, and Passion Flower Tinctures by HPLC-DAD and HPLC-MS. Chromatographia 53:210-215.

Bravo S, García-Alonso J, Martín-Pozuelo G, Gómez V, Santaella M, Navarro-González I, Periago MJ (2012). The influence of post-harvest UV-C hormesis on lycopene, $\beta$-carotene, and phenolic content and antioxidant activity of breaker tomatoes. Food Res Int 49:296-302.

Broughton W J, Hernandez G, Blair M, Beebe S, Gepts P, Vanderleyden J (2003). Beans (Phaseolus spp.)model food legumes. Plant and soil 252(1): 55-128.

Cetin ES (2014). Induction of secondary metabolite production by UV-C radiation in Vitis vinifera L. Öküzgözü callus cultures. Biol Res 47:37.

Chávez-Mendoza C, Sánchez E (2017). Bioactive compounds from Mexican varieties of the common bean (Phaseolus vulgaris): Implications for health. Molecules 22:1360.

Da Silva Rodrigues-Corrêa KC, Honda MD, Borthakur D, Fett-Neto AG (2019). Mimosine accumulation in Leucaena leucocephala in response to stress signaling molecules and acute UV exposure. Plant Physiol Biochem 135:432-440.

Dawar S, Khalid S, Tariq M (2013). Fungicidal effect of ultraviolet-C radiations in prevention of mycoflora of castor bean seeds. Archives of Phytopathology and Plant Protection 46:2125-2130.

Deckmyn G, Martens C, Impens I (1994). The importance of the ratio UV-B/photosynthetic active radiation (PAR) during leaf development as determining factor of plant sensitivity to increased UV-B irradiance: Effects on growth, gas exchange and pigmentation of bean plants (Phaseolus vulgaris cv. Label). Plant Cell Environ 17:295-301.

Dóka O, Ajtony Z, Bicanic D, Koehorst R (2000). Assessing the extent of degradation in the UV radiation and heat-catalyzed oxidized whole milk powder: The UV photoacoustic and diffuse reflectance spectroscopies versus the peroxide value. Appl. Spectrosc 54:1405-1408.

Edmondson JL, Davies ZG, Gaston K J, \& Leake J R (2014). Urban cultivation in allotments maintains soil qualities adversely affected by conventional agriculture. J Appl Ecol 51:880-889.

Ehsanpour AA, Razavizadeh R (2005) Effect of UV-C radiation on drought tolerance of alfalfa (Medicago sativa) callus. Pakistan J Biol Sci 8:1221-1224.

Elmnasser N, Guillou S, Leroi F, Orange N, Bakhrouf A, Federighi M (2007) Pulsed-light system as a novel food decontamination technology: a review. Can J Microbiol 53:813-821.

Farkas J (1998) Irradiation as method for decontaminating food: a review. Int J Food Microbiol 44:189-204.

FAO 2009a. High Level Expert Forum - How to Feed the World in 2050, Global agriculture towards 2050. Office of the Director, Agricultural Development Economics Division Economic and Social Development Department, Viale delle Terme di Caracalla, 00153 Rome, Italy. http://www.fao.org/fileadmin/templates/wsfs/docs/Issues_papers/HLEF2050_Global_Agriculture.pdf. 
FAO 2009b. High Level Expert Forum - How to Feed the World in 2050, "The technology challenge". Office of the Director, Agricultural Development Economics Division Economic and Social Development Department Viale delle Terme di Caracalla, 00153 Rome, Italy. http://www.fao.org/fileadmin/templates/wsfs/docs/Issues_papers/HLEF2050_Technology.pdf.

Ferreira CD, Ziegler V, Schwanz Goebel J T, Lang G H, Elias MC, de Oliveira M (2018) Quality of grain and oil of maize subjected to UV-C radiation $(254 \mathrm{~nm}$ ) for the control of weevil (Sitophilus zeamais Motschulsky). J Food Process Pres 42:e13453.

Forges M, Vàsquez H, Charles F, Sari D C, Urban L, Lizzi Y, Aarrouf J (2018) Impact of UV-C radiation on the sensitivity of three strawberry plant cultivars (Fragaria $\mathrm{x}$ ananassa) against Botrytis cinerea. Sci Hortic 240:603-613.

Gani A, Bashir M, Wani S M, Masoodi FA (2012) Modification of bean starch by $\gamma$-irradiation: Effect on functional and morphological properties. LWT- Food Sci Technol 49:162-169.

Godfray HJC, Beddington JR, Crute IR, Haddad L, Lawrence D, Muir JF (2010) Food security: the challenge of feeding 9 billion people. Science 327:812-818.

Gomez-Lopez VM, Ragaert P, Debevere J, Devlieghere F (2007) Pulsed light for food decontamination: a review. Trends in food science \& technology 18:464-473.

Grela ER, Kiczorowska B, Samolińska W, Matras J, Kiczorowski P, Rybiński W, Hanczakowska E (2017) Chemical composition of leguminous seeds: part I—content of basic nutrients, amino acids, phytochemical compounds, and antioxidant activity. Eur Food Res Technol 243:1385-1395.

Guajardo-Flores D, Serna-Guerrero D, Serna-Saldívar SO, Jacobo-Velázquez DA (2014) Effect of Germination and UV-C Radiation on the Accumulation of Flavonoids and Saponins in Black Bean Seed Coats. Cereal Chem 91:276-279.

Hamid N, Jawaid F (2011) Influence of seed pre-treatment by UV-A and UV-C radiation on germination and growth of Mung beans. Pakistan J. Chem 1:164-167.

Hernández-Aguilar C, Aquiles CC, Artola A, Michtchenko A (2006) Laser irradiation effects on maize seed field performance. Seed Sci Technol 34:193-197.

Hernández-Aguilar C, Carballo AC, Michtchenko A, López-Bonilla J (2007) Pre-treatment laser light on maize seed vigor. International E-journal Engineering Mathematics: Theory and Application 1:87-94.

Hernández-Aguilar C, Domínguez-Pacheco FA, Carballo CA, Cruz OA, Ivanov R, López BJL, MJP Valcarcel (2009) Alternating magnetic field irradiation effects on three genotype maize seed field performance. Acta Agrophys 170:7-17.

Hernández-aguilar C, Dominguez-Pacheco FA, Cruz-Orea A, Ivanov R, Carballo CA, Zepeda BR (2010) Laser in agriculture. Int Agrophys 24:407-422.

Hernández-Aguilar C, Domínguez-Pacheco FA, Cruz-Orea A, Podleśna A, Ivanov R, Carballo CA, LópezBonilla J L (2016) Bioestimulación láser en semillas y plantas. Gayana Bot 73:132-149. 
Hussain PR, Wani IA, Suradkar PP, Dar MA (2014) Gamma irradiation induced modification of bean polysaccharides: Impact on physicochemical, morphological and antioxidant properties. Carbohyd polym 110:183-194.

Hyun-Jung, Ch, Qiang L (2010) Molecular structure and physicochemical properties of potato and bean starches as affected by gamma-irradiation. Int J Biol Macromol 47:214-222.

Hunt JE, McNeil DL (1998) Nitrogen status affects UV-B sensitivity of cucumber. Aust J Plant Physiol 25:7986.

Irakli M, Chatzopoulou P, Ekateriniadou L (2018) Optimization of ultrasound-assisted extraction of phenolic compounds: Oleuropein, phenolic acids, phenolic alcohols and flavonoids from olive leaves and evaluation of its antioxidant activities. Ind Crops Prod 124:382-388.

Kara Y (2013) Morphological and physiological effects of UV-C radiation on bean plant (Phaseolus vulgaris). Biosci Res 10:29-32.

Katerova ZI, Todorova D (2009) Endogenous polyamines lessen membrane damages in pea plants provoked by enhanced ultraviolet-C radiation. Plant Growth Regul 57:145-152.

Katerova Z, Todorova D, Tasheva K, Sergiev I (2012) Influence of ultraviolet radiation on plant secondary metabolite production. Genet Plant Physiol 2:113-144.

Lazim SK, Nasur AF (2017) The effect of magnetic field and ultraviolet-C radiation on germination and growth seedling of sorghum (Sorghum bicolor L. Moench). IOSR Journal of Agriculture and Veterinary Science (IOSR-JAVS) 10:30-36.

Lin L, Harnly JM, Pastor-corrales MS, Luthria DL (2008) The polyphenolic profiles of common bean (Phaseolus vulgaris L.). Food Chem 107:399-410. http://doi.org/10.1016/j.foodchem.2007.08.038

Maffei ME (2014) Magnetic field effects on plant growth, development, and evolution. Front Plant Sci 5:445.

Mariz-Ponte N, Mendes RJ, Sario S, Melo P, Santos C (2018) Moderate UV-A supplementation benefits tomato seed and seedling invigoration: a contribution to the use of UV in seed technology. Sci Hort 235:357-366.

Marinković B, Grujić M, Marinković D, Crnobarac J, Marinković J, Jaćimović G, Mircov DV (2008) Use of biophysical methods to improve yields and quality of agricultural products. J Agric Sci 53:235-242.

Hungria M, Johnston AWB, Phillips DA (1992) Effects of flavonoids released naturally from bean (Phaseolus vulgaris) on nodD-regulated gene transcription in Rhizobium leguminosarum bv Phaseoli. Mol Plant Microbe Interact 5:199-203.

Maugh TH (1975) Photoacoustic spectroscopy: new uses for an old technique. Science 188:38-39.

Meenashree B, Kathiravan G, Manickamoorthi N (2018) Estimation of Metabolites and Antioxidant Activity in UV-C Treated Callus Cultures of Bacopa monnieri (Linn.) Pennell. SCIOL Biotechnol 1:9-14.

Meneses-Reyes JC, Soto-Hernández RM, Espinosa-Solares T, Ramírez-Guzmán ME (2008) Optimización del proceso de extracción de flavonoides de flor de manzanilla (Matricaria recutita L.). Agrociencia 42:425-433.

Mukhopadhyay S, Ramaswamy R (2012) Application of emerging technologies to control Salmonella in foods: A review. Food Res Int 45:666-677. 
Neelamegam R, Sutha T (2015) UV-C irradiation effect on seed germination, seedling growth and productivity of groundnut (Arachis hypogaea L.). Int J Curr Microbiol App Sci 4:430-443.

Occhipinti A, De Santis A, Maffei ME (2014) Magnetoreception: an unavoidable step for plant evolution?. Trends Plant Sci 19:1-4.

Páez CLR, Reyes MCP, Aguilar CH, Pacheco FAD, Martínez EM, Orea AC, Bonilla JLL (2011) Control of natural mycobiota in maize grains by ultraviolet (UVC) irradiation. Acta Agrophys 18:193.

Peykarestan B, Seify M (2012) UV irradiation effects on seed germination and growth, protein content, peroxidase and protease activity in redbean. IRJABS 3:92-102.

Reynoso Camacho R, Ríos Ugalde MDC, Torres Pacheco I, Acosta Gallegos JA, Palomino Salinas AC, Ramos Gómez M, Guzmán Maldonado SH (2007) El consumo de frijol común (Phaseolus vulgaris L.) y su efecto sobre el cáncer de colon en ratas Sprague-Dawley. Agricultura técnica en México 33:43-52.

Rifna EJ, Ramanan KR, Mahendran R (2019) Emerging technology applications for improving seed germination. Trends Food Sci Techno https://doi.org/10.1016/j.tifs.2019.02.029

Rupiasih NN, Vidyasagar PB (2016). Effect of UV-C radiation and hypergravity on germination, growth and content of chlorophyll of wheat seedlings. In AIP Conference Proceedings 1719:030035. AIP Publishing.

Santos AL, Oliveira V, Baptista I, Henriques I, Gomes NC, Almeida A, Cunha Â (2013) Wavelength dependence of biological damage induced by UV radiation on bacteria. Archives of microbiology 195:63-74.

Shetta DN, Areaf MI (2009) Impact of ultraviolet-C radiation on seed germination and chlorophyll concentration of some woody trees grown in Saudi Arabia. J Agric Environ Sci 8:1-21.

Shetty P, Atallah MT, Shetty K (2002) Effects of UV treatment on the proline-linked pentose phosphate pathway for phenolics and L-DOPA synthesis in dark germinated Vicia faba. Process Biochem 37:1285-1295.

Siddiqui A, Dawar Shahna Z, Zaki MJ, Hamid N (2011) Role of ultra violet (UV-C) radiation in the control of root infecting fungi on groundnut and mung bean. Pak. J. Bot, 43:2221-2224.

Singh J, Kaur L, Singh H (2013) Food Microstructure and starch digestión. In Jeyakumar Henry, editor: Avances in Food and Nutrition Research. Burlington: Academic Press 70:137-179.

Solecka D (1997) Role of phenylpropanoid compounds in plant responses to different stress factors. Acta Physiol Plant 19:257-268.

Stapleton AE (1992) Ultraviolet radiation and plants: burning questions. Plant Cell 4:1353-1358.

Strack D (1997) Phenolic Metabolism. P.M. Dey: J.B. Harbourne (Eds.), Plant Biochemistry, Academic Press, San Diego, pp. 387-416.

Sukthavornthum W, Bodhipadma K, Noichinda S, Phanomchai S, Deelueak U, Kachonpadungkitti Y, Leung DW (2018) UV-C irradiation induced alterations in shoot proliferation and in vitro flowering in plantlets developed from encapsulated and non-encapsulated microshoots of Persian violet. Sci Hort 233:9-13.

Thomas Dhanya TT, Puthur JT (2017) UV radiation priming: a means of amplifying the inherent potential for abiotic stress tolerance in crop plants. Environ Exp Bot 138:57-66.

Torres CMT (2001) Estudio químico y anatómico de dos variedades de frijol (Phaseolus vulgaris L.) cambios postcosecha. Tesis Doctoral, Universidad Autónoma de Nuevo León, Nuevo León, México. 
1 Torres M, Frutos G, Duran JM (1991) Sunflower seed deterioration from exposure to UV-C radiation. Environ 2 Exp Bot 31:201-207.

3 Urban L, Charles F, de Miranda MRA, Aarrouf J (2016) Understanding the physiological effects of UV-C light 4 and exploiting its agronomic potential before and after harvest. Plant Physiol Biochem 105:1-11.

5

6 Vasilevski G (2003) Perspectives of the application of biophysical methods in sustainable agriculture. Bulg. J.

7 Plant Physiol 29:179-186. 